\title{
Pengaruh Kelompok Kerja Guru (KKG) Terhadap Peningkatan Kompetensi Pedagogik dan Kemampuan Menulis Karya Ilmiah
}

\author{
Arsyad $^{1)}$ Wahyu Bagja Sulfemi ${ }^{2)}$ \\ 1) STKIP Muhammadiyah Bogor \\ Email: arsyaddjamaluddin@gmail.com \\ 2) STKIP Muhammadiyah Bogor \\ E-mail:wahyubagja@gmail.com
}

\begin{abstract}
Abstrak. Penelitian ini bertujuan mengetahui pengaruh peningkatan kompetensi pedagogik guru dan kemampuan penulisan kemampuan menulis karya ilmiah guru terhadap Kegiatan Kelompok Kerja Guru (KKG). Metode yang digunakan dalam penelitian ini adalah metode survei dengan teknik analisis jalur (path analysis) untuk memperoleh fakta-fakta dari gejala-gejala yang ada dan mencari keterangan secara factual dengan menggunakan pendekatan kuantitatif sebagai tumpuan analisis teknik regresi untuk menguji hipotesis yang menyatakan ada atau tidak pengaruh variabel bebas $\left(\mathrm{X}^{1}\right)$ dan $\left(\mathrm{X}^{2}\right)$ dengan variabel terikat $(\mathrm{Y})$. Populasi dalam penelitian ini adalah guru Sekolah Dasar (SD) anggota KKG Gugus 1 dan 2 Kecamatan Ciampea sebanyak 95 orang dengan jumlah Sampel penelitian ini berjumlah 25 guru. Hasil dari penelitian, pertama, terdapat pengaruh positif kegiatan KKG (Y) terhadap pengingkatan kompetensi pedagogik guru $\left(\mathrm{X}^{1}\right)$, dengan indeks korelasi $\mathrm{r} \mathrm{y}^{1}=3,27$ dengan hasil uji koefisien korelasi yang signifikan pada $\alpha=5 \%$ serta diperjelas bahwa $80 \%$ variasi Y dipengaruhi oleh $\mathrm{X}^{1}$. Kedua, terdapat pengaruh kegiatan KKG (Y) dengan kemampuan menulis karya ilmiah $\left(\mathrm{X}^{2)}\right.$, dengan koefisien korelasi $\mathrm{r} \mathrm{y}^{2}$ $=3,32$ dengan hasil uji koefisien korelasi yang signifikan pada $\alpha=5 \%$ serta diperjelas bahwa $80 \%$ variasi Y dipengaruhi oleh $\mathrm{X}^{2}$. Ketiga terdapat pengaruh positif kegiatan $\mathrm{KKG}(\mathrm{Y})$ dengan pengingkatan kompetensi pedagogik guru $\left(\mathrm{X}^{1}\right)$ dan kemampuan menulis karya ilmiah $\left(\mathrm{X}^{2)}\right.$, dengan koefisien korelasi ganda Ry.12=4,76 dengan hasil uji koefisien korelasi yang signifikan pada $\alpha=5 \%$ serta diperjelas bahwa $80 \%$ variasi Y dipengaruhi oleh $\mathrm{X}^{1}$ dan $\mathrm{X}^{2}$. Melalui analisa pengujian diperoleh bahwa koefisen korelasi dan koefisien regresi tersebut sangat signifikan. Hal tersebut membuktikan bahwa terdapat hubungan yang positif dan sangat signifikan antara peningkatan kompetensi pedagogik dan kemampuan menulis karya ilmiah dengan kegiatan KKG
\end{abstract}

Kata Kunci: Kelompok Kerja Guru; Kompetensi Pedagogik; Menulis; Karya Ilmiah

\section{PENDAhUluaN}

Pengembangan sumber daya manusia pendidik, khususnya pengembangan profesional guru, merupakan usaha mempersiapkan guru agar memiliki berbagai wawasan, pengetahuan, keterampilan, dan memberikan rasa percaya diri untuk melaksanakan tugas dan kewajibannya sebagai petugas profesional. Pengembangan atau peningkatan kemampuan profesional harus bertolak pada kebutuhan atau permasalahan nyata yang dihadapi oleh guru, agar bermakna. Undangundang Republik Indonesia Nomor 14 Tahun 2005 tentang Guru dan Dosen pasal 20, mengamanatkan bahwa dalam rangka melaksanakan tugas keprofesionalannya, guru berkewajiban meningkatkan dan mengembangkan kualifikasi akademik dan kompetensi secara berkelanjutan sejalan dengan perkembangan ilmu pengetahuan, teknologi, dan seni [1]. Kompetensi merupakan prilaku yang rasional untuk mencapai tujuan yang di prasyaratkan sesuai dengan kondisi yang diharapkan, artinya bahwa kompetensi adalah the state of being legally competent or qualified, yakni keadaan berwenang atau memenuhi syarat menurut ketentuan hukum. Kompetensi guru (tenaga pendidik) atau "teacher competence" ialah the ability of a teacher to responsibly perform his or her duties appropriately. Kompetensi guru merupakan kemampuan seseorang guru dalam melaksanakan kewajiban-kewajibannya secara tanggungjawab dan layak[2].

Idealnya, guru pada zaman milenial ini menjadi penggiat literasi agar memiliki cakrawala atau wawasan yang komprehensif. Sumber-sumber belajar sudah sangat banyak 
dan mudah ditemukan. Sumber yang berkaitan dengan tugas gurulah yang menjadi prioritas untuk dibaca. Guru hendaknya memiliki keinginan yang kuat untuk mendalami ilmu pengetahuan dan teknologi secara terus menerus[3]. Melalui membaca inilah nantinya dapat menunjukkan kemampuan guru untuk mengatasi pembelajaran melalui penelitianpenelitian. Jangan sampai guru lebih rajin membaca dan menjawab WhatsApp, Facebook, Twitter, dan media sosial lainnya dari pada membaca buku, hasil penelitian untuk kepentingan profesionalnya. Berkaitan dengan hal tersebut, guru sebagai pendidik professional, ia dituntut untuk mengembangkan profesinya melalui.

Fakta di lapangan menunjukkan bahwa berdasarkan data hasil ujian kompoetensi guru (UKG) tahun 2015, menunjukkan bahwa hasil nilai rata-rata guru secara nasional belum mencapai 70 poin. Guru yang memiliki kompetensi di atas rata-rata atau lulus UKG dengan nilai minimal 80 tidak lebih dari 30 persen. Berdasarkan hasil UKG tersebut menjelaskan bahwa redahnya kompetensi guru tergambar pada hasil: (a) Nilai kompetensi guru secara nasional kategorinya belum lulus, jauh dibawah nilai standar 80 yang dipersyaratkan pemerintah. (b) Guru yang sudah bersertifikat pendidik ternyata juga belum mampu menunjukkan peningkatan kompetensi secara signifikan dan berkelanjutan. (c) Guru mengalami kesulitan dalam memenuhi tuntutan Permenneg PAN dan RB Nomor 16 Tahun 2009, untuk kenaikan pangkat yang mempersyaratkan harus publikasi ilmiah dengan karya ilmiah.

Peningkatan kompotensi pedagogik guru dalam melaksanakan dan mengefektifkan proses pembelajaran di kelas, akan memberikan dampak terhadap aspek kualitas kegiatan proses pembelajaran. Penguasaan terhadap materi seorang guru sangat berpengaruh dalam meningkatkan mutu proses pembelajaran di kelas [4]. Saat ini banyak guru yang telah melaksanakan teori konstruktivisme dalam pembelajaran di kelas tetapi volumenya masih terbatas, karena kenyataan dilapangan masih banyak guru yang dalam mengajar masih terkesan hanya melaksanakan kewajiban, tidak menggunakan strategi, metode dalam mengajar, baginya yang penting bagaimana sebuah peristiwa pembelajaran dapat berlangsung.

Dalam implementasinya di lapangan, baik faktor kompetensi pedagogik maupun kemampuan menulis karya ilmiah, belum mampu menmperlihatkan komepertensi guru yang sesungguhnya, terutama dalam peningkatan mutu pendidikan, hal ini tercermin dari; (a) guru masih kesulitan dalam mengelola kelas, terutama dalam menggunakan metode, strategi dan pendekatan pemeblajaran yang menyenangkan bagi siswa; (b) masih banyak guru yang tidak menekuni profesinya secara utuh, tidak ada waktu untuk membaca dan menulis, dan motivasi kurangnya dalam meningkatkan kualitas diri, terutama dalam meneliti untuk menghasilkan karya; (c) guru masih kesulitan dalam menulis dan publis karya ilmiah. Persoalan tersebut muncul karena selama ini guru tidak optimal dalam mengembangkan diri melalui wadah atau organisasi keilmuan yang bersifat independen, seperti organisasi KKG.
Merujuk pada Permenneg PAN dan RB Nomor 16 Tahun 2009, pasal 11 ayat c, tentang Komponen Pengembangan Keprofesian Berkelanjutan (PKB) bagi guru, meliputi; pengembangan diri, publikasi ilmiah dan karya inovatif [5]. Pengembangan karir guru profesional wajib memenuhi syarat berupa penulisan karya ilmiah. Untuk menghasilkan pubklikasi ilmiah, guru harus mampu menghasilkan karya ilmiah berupa hasil penelitian atau gagasan inovatif pada bidang pendidikan formal; publikasi buku teks pelajaran, dan buku pengayaan. Hasil karya ilmiah tersebut dipublikasikan dalam seminar atau lokakarya ilmiah, pada koloqium atau diskusi ilmiah, melalui laporan hasil penelitian dalam bentuk buku ber ISBN dan diedarkan secara nasional, laporan hasil penelitian dipublikasikan dalam majalah/jurnal ilmiah tingkat nasional/provinsi/kabupaten/kota.

Guru dituntut untuk melakukan pengembangan keprofesian secara berkelanjutan untuk meningkatkan kemampuan mengajarnya dan kemampuan untuk menulis dan menulis karya ilmiah. pengembangan keprofesian guru secara berkelanjutan dapat dilakukan melalui kegiatan organisasi keilmuan guru seperti di KKG. Kegiatan di KKG menjadi wadah komunikasi, pembinaan, dan peningkatan kompetensi pedagogik dan karier guru dan keprofesian secara berkelanjuta yang terpercaya. Kegiatan di KKG akan mengembangkan pengetahuan dan wawasan serta kesiapan bagi guru tentang; (a) penyiapan rencana pembelajaran, pelaksanaan pembelajaran, dan perangkat penilaian hasil pembelajaran. (b) Kemampuan guru dalam menulis dan menghasilkan karya ilmiah. Karya ilmiah yang dipublikasikan oleh guru merupakan salah satu barometer peningkatan kompetensi guru yang layak dikatakan professional.

Kempok Kerja Guru (KKG) adalah organisasi guru nonstruktural yang bersifat keilmuan, mandiri, dan tidak mempunyai hubungan hirarkis dengan lembaga lain. KKG sebagai wadah keilmuan dalam pengembangan kompetensi profesionali guru SD yang bertujuan untuk: (a) memfasilitasi kegiatan yang dilakukan di pusat kegiatan guru SD berdasarkan masalah dan kesulitan yang dihadapi, (b) memberikan bantuan profesional kepada para guru SD di sekolah, (c) meningkatkan pemahaman, keilmuan, keterampilan serta pengembangan sikap profesional guru SD berdasarkan kekeluargaan dan saling mengisi (sharing), (d) meningkatkan pengelolaan proses pembelajaran yang aktif, kreatif, dan menyenangkan. Hal ini sejalan dengan hasil penelitian Harun Al Rasyid, bahwa keberadaan kelompok atau musyawarah guru sangat membantu dalam melaksanakan tugas profesinya, baik dalam membahas atau mendiskusikan materi pelajaran yang maupun dalam pengembangan media pembelajaran [6]. KKG sangat penting bagi seorang pendidik yang memahami fungsi dan tugasnya guru khususnya dibekali dengan berbagai ilmu keguruan sebagai dasar, disertai pula dengan seperangkat latihan keterampilan keguruan dan pada kondisi itu pula guru belajar memersosialisasikan sikap keguruan yang diperlukan.

Keberhasilan pengembangan kompetensi pedagogik dan kemampuan menulis karya ilmiah bagi guru SD melalui kegiatan di KKG terefleksi pada kemampuan: (a) guru mampu melakukan pengembangan dan evaluasi diri secara 
berkelanjutan (b) Guru mampu melakukan penelitian, mengembangkan karya inovasi, mengikuti kegiatan ilmiah (seminar, konferensi). (c) Penguasaan materi, struktur, konsep, dan pola pikir keilmuan yang mendukung mata pelajaran yang diampu, dan mampu memanfaatkan TIK dalam berkomunikasi dan pelaksanaan pembelajaran di sekolah [7].

Dengan demikian, dapat diasumsikan bahwa melalui pengembangan keprofesian guru melalui kegiatan di $\mathrm{KKG}$, guru dapat meningkatkan kompetensi pedagogiknya dan sekaligus dapat mengembangkan kemampuannya untuk menulis karya ilmiah sebagai bagian dari ciri guru yang profesional. Untuk itu, urgensi penelitian ini kaitannya dengan pengembangan profesional berkelanjutan (continuous professional development) melalui peran KKG sebagai organisasi keilmuan guru sekolah dasar (SD) yang mandiri melalui perencanaan, pelaksanaan dan evaluasi kegiatan sebagai wadah peningkatan kompetensi pedagogik dan kemampuan menulis karya ilmiah, menjadi salah satu ciri dari guru profesional.

\section{MetoDE PENELITIAN}

Metode yang digunakan dalam penelitian ini adalah metode survei dengan teknik analisis jalur (path analysis) untuk memperoleh fakta-fakta dari gejala-gejala yang ada dan mencari keterangan secara factual dengan menggunakan pendekatan kuantitatif sebagai tumpuan analisis teknik regresi untuk menguji hipotesis yang menyatakan ada atau tidak pengaruh variabel bebas $\left(\mathrm{X}^{1}\right)$ dan $\left(\mathrm{X}^{2}\right)$ dengan variabel terikat (Y). Populasi dalam penelitian ini adalah guru Sekolah dsar (SD) anggota KKG Gugus 1 dan 2 Kecamatan Ciampea sebanyak 95 orang. Sampel penelitian ini berjumlah 25 guru SD anggota KKG gugus 1 dan 2 kecamatan Ciampea Bogor, dengan teknik pengambilan sampel yang digunakan adalah teknik random sampling, dengan cara undian. Pengumpulan data dilakukan yaitu; data untuk kompetensi pedagogik diambil dengan menggunakan tes kemampuan mengajar, yaitu; (a) kemampuan mengelola pembelajaran peserta didik, (b) perancangan dan pelaksanaan pembelajaran, (c) evaluasi hasil belajar, (d) pengembangan peserta didik untuk mengaktualisasikan berbagai potensi yang dimilikinya, dengan indikator persiapan, pelaksanaan dan penilaian pembelajaran. Data hasil kemampuan menulis dan publikasi karya ilmiah diambil menggunakan koesioner yang disampaikan langsung kepada responden, dengan indikator yaitu; keterampilan mengekspresikan ide atau gagasan, keterampilan mengorganisasikan ide atau gagasan tersebut, keterampilan menerapkan gramatika dan pola-pola sintaksis, keterampilan memilih struktur dan kosakata, dan keterampilan mekanik, yaitu menggunakan konvensi grafik bahasa. Sementara indikator peran KKG yaitu; mengembangkan keterampilan dalam memperoleh pengetahuan, keterampilan dalam pengembangan jati diri, keterampilan dalam pelaksanaan tugas tertentu, dan keterampilan untuk dapat hidup berdampingan dengan sesama guru dan siswa secara harmonis.

Analisis regresi yaitu ingin menguji apakah ada atau tidak ada pengaruh antara variabel bebas dan variabel terikat.
Sedangkan analisis korelasi ingin mengetahui seberapa besar tingkat keeratan peran antar variabel terikat dengan variabel bebas dan agar hasil keputusannya dapat dipertanggung jawabkan, maka koefisien korelasi perlu diuji signifikansinya. Dari kajian literatur di atas dapat dipahami bahwa diantara faktor untuk meningatkan kompetensi pedagogik dan kemampuan menulis dan publikasi karya ilmiah melalui peran kegiatan KKG sebagai wadah peningkatan kompetensi pedagogik dan kemampuan menulis karya ilmiah bagi guru SD.

\section{HASIL DAN PEMBAHASAN}

\section{Hasil Penelitian}

Kompetensi Guru

Untuk instrument kompetensi guru diambil melalui koesioner, dengan standar nilai 60 - 80. Dari jumlah data sebanyak 25 responden untuk varibel kompetensi guru SD ini diperoleh skor terendah 62, dan nilai tertinggi skor 77, dengan rentang 15 , interval 5 , banyak Interval 4 , median 70 , modus 75 dan rerata 3,72 . Untuk lebih jelasnya dapat dilihat pada tabel 1 di bawah ini.

TABEL.1

\begin{tabular}{|c|c|c|}
\hline DISTRIBUSI & FREFKUENS & KOMPETENSI GURU \\
\hline $\begin{array}{c}\text { Interval Kelas } \\
60-65\end{array}$ & Frekuensi & Frekuensi $(\%)$ relative \\
\hline $66-70$ & 9 & 36 \\
\hline $71-75$ & 10 & 40 \\
\hline $76-80$ & 3 & 12 \\
\hline$\Sigma$ & 25 & 100 \\
\hline
\end{tabular}

\section{Kemampuan Menulis karya Ilmiah}

Untuk instrument kemampuan menulis karya ilmiah diambil melalui koesioner, dengan standar nilai $60-80$. Dari jumlah data sebanyak 25 responden untuk varibel pendidikan dan pelatihan ini diperoleh skor terendah 62, dan nilai tertinggi skor 80 , dengan rentang 18 , interval 5, banyak Interval 4, median 75, modus 80 dan rerata 2,2. Untuk lebih jelasnya dapat dilihat pada tabel 2 di bawah ini.

TABEL. 2

DISTRIBUSI FREKUENSI MENULIS KARYA ILMIAH

\begin{tabular}{ccc}
\hline Interval Kelas & Frekuensi & Frekuensi (\%) relatif \\
\hline $60-65$ & 3 & 12 \\
$66-70$ & 5 & 20 \\
$71-75$ & 7 & 28 \\
$76-80$ & 10 & 40 \\
\hline$\Sigma$ & 25 & 100 \\
\hline
\end{tabular}

\section{Peran Kelompok Kerja Guru (KKG)}

Untuk instrument peran KKG gugus1 dan 2 kecamatan Ciampea Bogor diambil melalui koesioner, dengan standar nilai 60 - 80. Dari jumlah data sebanyak 25 responden untuk varibel kompetensi mengajar ini diperoleh skor terendah 60 , dan nilai tertinggi skor 80, dengan rentang 20, interval 5, banyak Interval 4, median 70 , modus 75 dan rerata 2,8 . Untuk lebih jelasnya dapat dilihat pada tabel 3 berikut: 
TABEL. 3

DISTRIBUSI FREKUENSI PERAN KKG

\begin{tabular}{ccc} 
Interval Kelas & Frekuensi & Frekuensi $(\%)$ relative \\
\hline $60-65$ & 5 & 20 \\
$66-70$ & 5 & 20 \\
$71-75$ & 10 & 40 \\
$76-80$ & 5 & 20 \\
\hline$\Sigma$ & 25 & 100
\end{tabular}

Selanjutnya disajikan hasil penelitian yang diperoleh dari; 1) data tentang kompetensi pedagogik guru, 2) data kemampuan menulis karya ilmiah dan 3) data peran KKG diperoleh menggunakan koesioner, dengan 4 pilihan yang disampaikan kepada responden untuk dipilih sesuai dengan keadaan diri responden. Berikut rangkuman analisis hasil perhitungan koefisien korelasi dan koefisien dan hasil uji signifikan koefisien korelasi sebagai berikut;

TABEL. 4

HASIL PERHITUNGAN KOEFISIEN KORELASI

\begin{tabular}{ll}
\hline Korelasi & Koefisien korelasi \\
\hline ry1 & 0,352 \\
ry2 & 0,544 \\
Ry.12 & 0,631 \\
\hline
\end{tabular}

TABEL. 5

HASIL UJI SIGNIFIKAN KOEFISIEN KORELASI

\begin{tabular}{llll}
\hline Korelasi & T-hitung & T-tabel & $\begin{array}{l}\text { Kesimpulan koefisien } \\
\text { korelasi }\end{array}$ \\
\hline ry1 & 3,27 & $(0,95,38) 1,69$ & $\begin{array}{l}\text { T-hit }>\text { tabel, koef } \\
\text { korelasi signifikan }\end{array}$ \\
\hline ry2 & 3,32 & $(0,95,38) 1,69$ & $\begin{array}{l}\text { T-hit }>\text { tabel, koef } \\
\text { korelasi signifikan }\end{array}$ \\
\hline Ry.12 & 4,76 & $(0,05 ; 2 / 37)$ & $\begin{array}{l}\text { T-hit }>\text { tabel, koef } \\
\text { korelasi signifikan }\end{array}$ \\
\hline
\end{tabular}

Dari hasil perhitungan analisis korelasi seperti disajikan pada tabel diatas, dapat diartikan: Pertama, terdapat pengaruh positif yang signifikan antara variabel $\mathrm{X}^{1}$ dengan variabel $\mathrm{Y}$, dengan adanya korelasi $\mathrm{r} \mathrm{y}^{1}=3,27$ dengan hasil uji koefisien korelasi yang signifikan pada $\alpha=5 \%$ serta diperjelas bahwa $80 \%$ variasi Y dipengaruhi oleh $\mathrm{X}^{1}$. Kedua, terdapat pengaruh positif yang signifikan antara variabel $\mathrm{X}^{2}$ dengan variabel $\mathrm{Y}$, dengan adanya korelasi $\mathrm{r} \mathrm{y}^{2}=3,32$ dengan hasil uji koefisien korelasi yang signifikan pada $\alpha=5$ $\%$ serta diperjelas bahwa $80 \%$ variasi $\mathrm{Y}$ dipengaruhi oleh $\mathrm{X}^{2}$. Ketiga, terdapat pengaruh positif yang signifikan antara variabel $\mathrm{X}^{1}$ dan $\mathrm{X}^{2}$ dengan variabel $\mathrm{Y}$, dipertegas adanya korelasi $\mathrm{R}$ y. ${ }^{12}=4,76$ dengan hasil uji koefisien korelasi yang signifikan pada $\alpha=5 \%$ serta diperjelas bahwa $80 \%$ variasi Y dipengaruhi oleh $\mathrm{X}^{1}$ dan $\mathrm{X}^{2}$.

Berdasarkan uraian hasil perhiutngan analisis regresi dan korelasi dapat diartikan bahwa hasil penelitian ini adalah: Pertama. Terdapat pengaruh positif antara variabel peningkatan kompetensi paedagogik guru $\left(\mathrm{X}^{1}\right)$ dengan kegiatan di KKG (Y). Kedua. Terdapat pengaruh positif antara variabel kemampuan menulis karya ilmiah $\left(\mathrm{X}^{2}\right)$ dengan kegiatan di KKG (Y). Ketiga. Terdapat pengaruh positif antara variabel kompetensi paedagogik guru $\left(\mathrm{X}^{1}\right)$ dan kemampuan menulis karya ilmiah $\left(\mathrm{X}^{2}\right)$ dengan kegiatan di $\mathrm{KKG}(\mathrm{Y})$.

\section{Pembahasan Hasil Penelitian \\ Peningkatan Kompetensi Pedagogik Guru}

Menurut Suyanto dan Djihad Hisyam, bahwa kompetensi adalah seperangkat pengetahuan, keterampilan, dan perilaku yang harus dimiliki, dihayati, dan dikuasai oleh guru dalam melaksanakan tugas keprofesionalan guru adalah pendidik profesional dengan tugas utama mendidik, mengajar, membimbing, mengarahkan, melatih, menilai, dan mengevaluasi peserta didik pada pendidikan anak usia dini jalur pendidikan formal, pendidikan dasar, dan pendidikan menengah [8]. Kompetensi pedagogik guru merupakan kemampuan dalam kegiatan intensional atau yang disengaja yang bersifat normatif. Kemampuan ini dititikberatkan pada tugas guru dalam mengajar melalui tiga tahapan tugas mengajar, yaitu: Pertama, persiapan pengajaran, terdiri dari; perumusan tujuan pengajaran; pemilihan metode; pemilihan pengalaman mengajar; pemilihan bahan pelajaran, peralatan, cara membuka; pengembangan dan menutup pengajaran, (f) peranan dan pengelompokan peserta didik. Kedua, pelaksanaan pengajaran. Ketiga, evalausi dan penutup pembelajaran [9].

Merujuk pada hasil penelitian, sebagaimana dijelaskan di atas, bahwa kegiatan di KKG mempunyai pengaruh positif dengan peningkatan kompetensi pedagogik guru, dengan perhitungan korelasi bahwa terdapat pengaruh positif yang signifikan antara variabel $\mathrm{X}^{1}$ dengan variabel $\mathrm{Y}$, dengan adanya korelasi $\mathrm{r} \mathrm{y}^{1}=3,27$. Hal ini sejalan dengan Mulyasa, bahwa kegiatan KKG merupakan salah satu sarana untuk meningkatkan kemampuan diri guru dengan menciptakan dan mengembangkan metode pengajaran yang relevan, dan merupakan salah satu cara meningkatkan sumber daya guru [10]. Hal ini juga diperkuat hasil penelitian Hal ini Jupriyanto, dan Nuridin, Berdasarkan hasil data angket keterampilan mengajar guru dan aktivitas belajar siswa menunjuk bahwa ada dampak yang penting antara keterampilan mengajar guru terhadap aktivitas belajar siswa [11].

Melalui aktifitas guru di KKG tersebut, diharapkan permasalahan pembelajaran yang dihadapi guru di kelas dapat terpecahkan melalui diskusi dengan teman sejawat sehingga proses pembelajaran lebih efektif, dan bermutu. Guru merupakan faktor yang sangat dominan dan penting dalam pendidikan, oleh karena itu guru harus memiliki Kompetensi pedagogik untuk mengembangkan peserta didik secara utuh. Arsyad, Wahyu Bagja Sulfemi, bahwa dengan komptensi memungkinkan seorang guru mampu mengajar dengan baik, bukan sebatas memiliki pengetahuan yang memadai [12].

Dengan demikian, berdasarkan hasil penelitian ini dan dikuatkan oleh pendapat para ahli menegaskan bahwa peran KKG sangat penting dalam pengembangan keprofesian guru secara berkelanjutan, sehingga bisa meningkatkan komptensi pedagogik guru. Kegiatan di KKG sebagai kegiatan pengembangan diri melalui pertemuan rutin terjadwal, yang 
memberikan kemampuan; (a) pelatihan menulis dan publikasi karya ilmiah, berupa hasil penelitian atau gagasan inovatif dan publikasi buku teks pelajaran, buku pengayaan. (b) mengembangkan karya inovatif yang dapat berupa menemukan teknologi tepat guna, menemukan atau menciptakan karya seni, membuat atau memodifikasi alat pelajaran, dan mengikuti pengembangan penyusunan standar, pedoman, soal dan sejenisnya.

\section{Kemampuan Menulis Karya Ilmiah}

Menulis sebagai suatu komponen keterampilan berbahasa membutuhkan keahlian dari seseorang dalam menggunakan bentuk bahasa tulis untuk maksud komunikasi, seperti yang diungkapkan kemampuan menulis menuntut gagasan yang tersusun secara logis, diekspresikan dengan jelas, dan ditata secara menarik. Untuk itu, keterampilan menulis harus melibatkan berbgai keterampilan, yaitu (a) keterampilan mengekspresikan ide atau gagasan, (b) keterampilan mengorganisasikan ide atau gagasan tersebut, (c) keterampilan menerapkan gramatika dan pola-pola sintaksis, (d) keterampilan memilih struktur dan kosakata, dan (e) keterampilan mekanik, yaitu menggunakan konvensi grafik bahasa [13]. Menulis dapat diartikan sebagai suatu kegiatan untuk menyampaikan ide atau pesan kepada orang lain dengan menggunakan media bahasa tulis. Menurut Dalman, menulis pada dasarnya menuangkan bahasa ujaran ke dalam sebuah tulisan, yang menjadi mekanisme curahan ide, gagasan, atau ilmu yang dituliskan dengan struktur yang benar, berkoheransi dengan baik antarparagraf dan bebas dari kesalahan-kesalahan mekanik seperti ejaan dan tanda baca. [14].

Merujuk pada hasil penelitian bahwa terdapat pengaruh positif yang signifikan antara variabel $\mathrm{X}^{2}$ dengan variabel $\mathrm{Y}$, dengan adanya korelasi $r y^{2}=3,32$. Hal ini menjelaskan bahwa pengaruh KKG sebagai organisasi keilmuan yang mandiri menjadi sangat penting bagi guru terlibat secara aktif untuk mengembangkan kompetensi profersional secara terus menerus (on-going), dalam bentuk sharing konwledge, sharing best practices, peer teaching dan berbagi pengalaman antar guru dalam memecahkan masalah yang dihadapi, baik di dalam maupun di luar kelas, salah satunya adalah pengembangan kemampuan menulis karya Ilmiah. Sebagai karya ilmiah, hasil penelitian harus mampu menelaah masalah-masalah yang dihadapi berdasarkan nilai objektif yang tinggi, dengan ditopang oleh pengetahuan dan kemampuan yang dimiliki peneliti. Hal ini diperkuat hasil penelitian Arsyad, bahwa terdapat pengaruh positif antara hasil pembelajaran penelitian dengan kemampuan menulis karya ilmiah, seperti skripsi [15]. Karya ilmiah berupa hasil penelitian di dalamnya mencerminkan kemampuan peneliti dalam mengetengahkan pikiran-pikirannya melalui hasil penelitiannya sesuai dengan kompetensinya. Dalam melaksanakan penelitian sebagai karya ilmiah, guru harus mempunyai kemampuan penguasaan terhadap metodologi penelitian, diharapkan bahwa hasil karya ilmiah tersebut memberikan gagasan inovatif pada aspek yang dikaji.

Sebagai suatu proses kreatif, menulis mengalami suatu proses yang secara sadar dilalui dan secara sadar pula dilihat hubungan satu dengan yang lain, sehingga berakhir pada tujuan yang jelas. Selain itu, menulis merupakan suatu kegiatan yang produktif dan efektif.dengan tugas utama pendidik, mengajar, membimbing, mengarahkan, melatih, menilai, dan mengevaluasi peserta didik pada pendidikan anak usia dini jalur pendidikan formal, pendidikan dasar, dan pendidikan menengah.

\section{Pengaruh KKG pada Peningkatan Kompetensi Pedagogik dan Menulis Karya Ilmiah}

Kegiatan di KKG sangat memungkinkan guru untuk mengembanagkan kemampuan atau kompetensi mengajar dan kemampuan menulis karya ilmiah, karena: Pertama, kegiatan di KKG memungkinkan guru selalu berinteraksi dengan ilmu pengetahuan yang bisa menjadi bahan untuk menulis melalui bahan materi pelajaran. Kedua, guru selalu berinteraksi dengan siswa dalam pembelajaran di kelas yang bisa menjadi sumber tulisan. Ketiga, guru sering berinteraksi dengan dunia pendidikan dan berbagai kebijakannya yang dinamis yang selalu menuntutnya berpikir, mengeluarkan ide-ide inovatifnya melalui lomba menulis, dan media massa juga menyediakan rubrik pendidikan yang memungkinkan bagi guru untuk mengekspresikan gagasan inovatifnya. Keempat, guru mempunyai wadah keilmuan independen yang memungkinakn guru untuk belajar dan mengasah kemampuan, termasuk menulis karya ilmiah melalui jurnal. Karya ilmiah berupa hasil penelitian di dalamnya mencerminkan kemampuan peneliti dalam mengetengahkan pikiranpikirannya melalui hasil penelitiannya sesuai dengan kompetensinya [16]. Dalam melaksanakan penelitian sebagai karya ilmiah, guru harus mempunyai kemampuan penguasaan terhadap metodologi penelitian, diharapkan bahwa hasil karya ilmiah tersebut memberikan gagasan inovatif pada aspek yang dikaji. Hal ini sesuai dengan hasil penelitian yang membuktikan bahwa terdapat pengaruh positif yang signifikan antara variabel $\mathrm{X}^{1}$ dan $\mathrm{X}^{2}$ dengan variabel $\mathrm{Y}$, dipertegas adanya korelasi $\mathrm{R}$ y. ${ }^{12}=4,76$.

Karya ilmiah berupa hasil penelitian di dalamnya mencerminkan kemampuan peneliti dalam mengetengahkan pikiran-pikirannya melalui hasil penelitiannya sesuai dengan kompetensinya. Dalam melaksanakan penelitian sebagai karya ilmiah, guru harus mempunyai kemampuan penguasaan terhadap metodologi penelitian, diharapkan bahwa hasil karya ilmiah tersebut memberikan gagasan inovatif pada aspek yang dikaji. Hal ini sejalan dengan hasil penelitian menurut Arsyad, bahwa faktor fisiologis merupakan kondisi umum jasmani siswa, dan faktor psikologis merupakan faktor internal yang berpengaruh pada diri siswa dalam proses belajar diantaranya adalah inteleigensi, sikap, bakat, minat dan motivasi [17]. Artinya bahwa dengan kompetensin guru dalam mengajar dan kemampuan menulis karya ilmiah guru akan memberikan dampak psoitif pada siswa yaitu minat dan motivasi yang tinggi pada siswa untuk belajar.

Berdasarkan uraian hasil pembahasan diatas, bahwa peningkatan kompetensi pedagogik atau mengajar guru dan kemampuan menulis karya ilmiah, secara sendiri-sendiri dipengaruhi oleh kegiatan di KKG, sebagai modal utama yang 
dapat meningkatkan kompetensi dan kemampuan guru. Dengan demikian, guru yang ingin meningkatkan wawasan dan pengetahuannya tentang mengajar dan menulis karya ilmiah guru, maka ia harus terlibat secara aktif dalam kegiatan di KKG sebagai wadah pengembangan keprofesian csecara berkelanjutan melalui pelatihan dan penerapan

\section{KESIMPULAN}

Berdasarkan deskripsi data penelitian dan setelah dilalukan analisis maka dapat disimpulkan sebagai berikut: 1) Terdapat pengaruh yang signifikan kegiatan KKG terhadap peningkatan kompetensi pedagogik. 2) Terdapat pengaruh yang signifikan kegiatan KKG terhadap kemampuan menulis karya ilmiah. 3) Terdapat pengaruh yang signifikan kegiatan KKG terhadap peningkatan kompetensi pedagogik dan kemampuan menulis karya ilmiah.

Berdasarkan simpulan diatas dapat disaran sebagai berikut 1) Dalam kegiatan KKG hendaknya memberikan wawasan dan pengetahuan kepada guru secara berkelanjutan, dengan memberikan pengetahuan dan wawasan tentang kompetensi pedagogik, sehingga guru dapat mengembangkan dan menerapkan konsep, dan metode belajar di kelas dengan variatif dan pada akhirnmya siswa dapat mennyerap materi pelajaran dengan baik. 2) , Dalam kegiatan di KKG memberikan wawasan dan pengetahuan guru secara berkelanjutan tentang konsep dan latihan dalam menulis karya ilmiah, sehingga guru dapat pengetahuan dan wawasan untuk menulis karya ilmiah, sehingga dapat dikembangkan pola, model alat-alat peraga pembelajaran melalui penelitian tindakan kelas (PTK). 3) Dalam kegiatan di KKG hendaknya dikembangkan keterampilan dalam memperoleh pengetahuan (learning to know), keterampilan dalam pengembangan jati diri (learning to be), keterampilan dalam pelaksanaan tugastugas tertentu (learning to do), dan keterampilan untuk dapat hidup berdampingan dengan sesama secara harmonis (learning to live together) antar guru.

\section{DAFTAR PUSTAKA}

[1] Undang-Undang. N0. 14. Guru dan Dosen, Jakarta: Biro Hukum dan Organisasi Sekretaris Jenderal Diknas RI. 2005.

[2] Sulfemi, Wahyu Bagja \& Yuliana, D. Penerapan Model Pembelajaran Discovery Learning Meningkatkan Motivasi Dan Hasil Belajar Pendidikan Kewarganegaraan. Jurnal Rontal Keilmuan Pancasila dan Kewarganegaraan, 5(1), 17-30. 2019

[3] Sulfemi, Wahyu Bagja dan Yuliani, Nunung. Model Pembelajaran Contextual Teaching And Learning (CTL) Berbantu Media Miniatur Lingkungan Untuk Meningkatkan Hasil Belajar IPS. Edunomic : Jurnal Ilmiah Pendidikan Ekonomi Fakultas Keguruan Dan Ilmu Pendidikan.7 (2). 73-8. 2019.

[4] Sulfemi, Wahyu Bagja dan Minati, Hilga. Meningkatkan Hasil Belajar Peserta Didik Kelas 3 SD Menggunakan Model Picture And Picture dan Media Gambar Seri. JPSD. 4 (2), 228- 242. 2018.

[5] Kementerian Negara Pendayagunaan Aparatur Negara dan Reformas Birokrasi, (2009). Peraturan Menteri Negara Pendayagunaan Aparatur Negara dan Reformasi Birokrasi Nomor 16 Tahun 2009 tentang Jabatan Fungsional Guru dan Angka Kreditnya, Jakarta.
[6] Harun Al Rasyid. Fungsi Kelompok Kerja Guru (KKG) Bagi Pengembangan Keprofesionalan Guru Sekolah Dasar. Jurnal Sekolah Dasar, Tahun 24 Nomor 2, November 2015.(143-150).

[7] Sulfemi, Wahyu Bagja dan Mayasari, Nova. Peranan Model Pembelajaran Value Clarification Technique Berbantuan Media Audio Visual Untuk Meningkatkan Hasil Belajar IPS. Jurnal Pendidikan. 20. (1). 53-68. 2019.

[8] Suyanto dan Djihad Hisyam, Refleksi dan Reformasi Pendidikan Indonesia Memasuki Millenium III. Yogyakarta : Adi Cita. 2000.

[9] Sulfemi, Wahyu Bagja. Model Pembelajaran Kooperatif Mind Mapping Berbantu Audio Visual Dalam Meningkatkan Minat, Motivasi dan Hasil Belajar IPS. Jurnal PIPSI (Jurnal Pendidikan IPS Indonesia), 4(1), 13-19. 2019.

[10] Mulyasa, E. Menjadi Guru Profesional menciptakan Pembelajaran Kreatif dan Menyenangkan. Bandung: Rosdakarya. 2010

[11] Jupriyanto, dan Nuridin (2018). Pengaruh Keterampilan Mengajar Guru terhadap Aktivitas Belajar Siswa SD Negeri 04 Loning. Jurnal Pendidikan Dasar Indonesia, Volum 4 Nomor 1 bulan Maret tahun 2019. Page $14-18$

[12] Arsyad, Arsyad dan Sulfemi, Wahyu Bagja. (2018) Metode Role Playing Berbantu Media Audio Visual Pendidikan dalam Meningkatkan Belajar IPS. Jurnal Pendidikan Ilmu Pengetahuan Sosial Indonesia. 3 (2). $41-46$

[13] Gie, The Liang. Pengantar Dunia Karangan/Mengarang. Yogyakarta: Balai Bimbingan Mengarang. 2002.

[14] Dalman. Keterampilan Menulis. Jakarta: PT Raja Grafindo Persada 2012.

[15] Arsyad, Arsyad. Hubungan Antara Capaian Pembelajaran Dasar-Dasar Penelitian Dan Statistik Dengan Mutu Skripsi: Studi Analisis di STKIP Muhammadiyah Bogor. Khazanah Pendidikan: Jurnal Ilmiah Kependidikan 12 (2), 95-110. 2019.

[16] Sulfemi, Wahyu Bagja. Pengaruh Disiplin Ibadah Sholat, Lingkungan Sekolah, dan Intelegensi Terhadap Hasil Belajar Peserta Didik Mata Pelajaran Pendidikan Agama Islam. EDUKASI: Jurnal Penelitian Pendidikan Agama dan Keagamaan, 16 (2). 2018.

[17] Arsyad, Arsyad dan Salahudin, Salahudin. Hubungan Kemampuan Membaca Al Qur'an dan Minat Belajar Siswa Dengan Hasil Belajar Pendidikan Agama Islam (PAI). EDUKASI: Jurnal Penelitian Pendidikan Agama dan Keagamaan, p-ISSN: 1693-6418, e-ISSN: 2580-247X , 180. 2018. 